\title{
Rancang Bangun Alat Pelindung Proses Intubasi
}

\author{
Zulhamidi $^{1}$, Armen ${ }^{1}$ \\ ${ }^{1}$ Program Studi Teknik Industri Agro, Politeknik ATI Padang, Jalan Bungo Pasang Tabing, Padang, 25171, Indonesia
}

\section{ARTICLE INFORMATION}

Received: June 01, 2020

Revised: June 24, 2020

Accepted: June 28, 2020

\section{KEYWORD}

\begin{tabular}{l} 
Anthropometry \\
Ergonomic \\
Intubation \\
CORRESPONDENCE \\
\hline Name: Zulhamidi \\
E-mail: zulhamidi@gmail.com
\end{tabular}

\section{PENDAHULUAN}

Wabah Covid-19 yang melanda hampir seluruh negara di dunia telah mengakibatkan terganggunya aktivitas hampir disemua sektor kehidupan. Covid-19 yang awalnya berasal dari Negara Tiongkok mengakibatkan meningkatnya gangguan kesehatan dan potensi kematian pada orang yang telah terinfeksi penyakit ini. Rumah sakit merupakan tulang punggung utama penanganan masyarakat yang terinveksi virus sehingga mengakibatkan kenaikan resiko tertularnya setiap individu yang beraktivitas di rumah sakit seperti dokter, perawat, petugas kebersihan serta pasien lain.

Dokter merupakan subjek yang paling beresiko tertular penyakit Covid-19 karena mereka melakukan kontak langsung dengan pasien. Resiko penularan penyakit Covid19 terutama sekali datang dari orang yang tidak memiliki gejala (OTG) dimana tenaga kesehatan belum mempersiapkan diri dengan baik sehingga perlunya pencegahan yang optimal ketika terjadi kontak langsung dengan pasien. Ikatan Dokter Indonesia (2020), menyatakan bahwasanya berdasarkan data Indeks Pengaruh Kematian Nakes (IPKN) sampai dengan 21 Juli 2020, rasio kematian tenaga medis dan tenaga kesehatan dibanding dengan total kematian terkonfirmasi COVID-19 di Indonesia termasuk salah satu yang tertinggi diantara di negara lain, yaitu 2,4\%. Hal ini disebabkan oleh minimnya APD, kurangnya skrining pasien yang baik di fasilitas kesehatan, kelelahan para tenaga medis dan beberapa penyebab lainnya.

Salah satu gejala dari pasien Covid-19 adalah kesulitan bernafas dan salah satu teknik nafas yang dilakukan para dokter adalah proses tracheal intubation yaitu meletakkan plastik elastis ke dalam batang tenggorokan supaya aliran pernafasan pasien tetap bisa berjalan dengan baik (PERDATIN, 2020).

Proses intubation ataupun tindakan medis lain yang dilakukan oleh dokter merupakan jalur penularan penyakit yang paling cepat apabila tidak dilengkapi dengan Alat Pelindung Diri (APD) yang ketat dan lengkap. Penularan ini terjadi umumnya melalui droplet dan kontak dengan virus kemudian virus dapat masuk ke dalam mukosa yang terbuka (Handayani et al., 2020). Department of Anesthesiology Uttaradit Hospital, Thailand telah mengembangkan sebuah alat yang berfungsi mencegah proses terjadinya penularan dari pasien ke tenaga medis terutama dari percikan air liur seperti dapat dilihat pada Gambar 2 di bawah ini. 


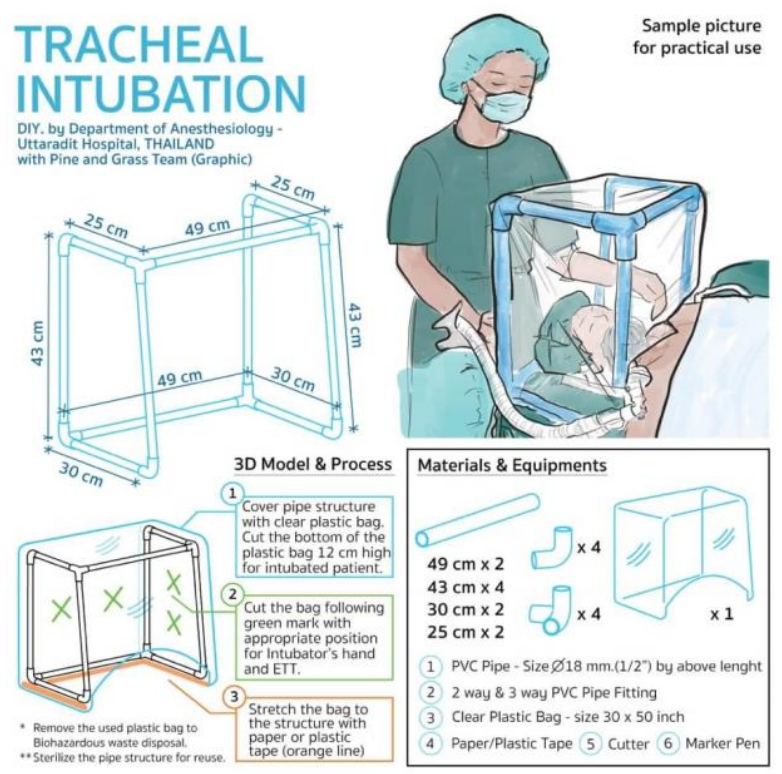

Gambar 1. Peralatan Pelindung Proses Intubasi

(Department of Anesthesiology Uttaradit Hospital, Thailand)

Alat intubasi tersebut masih ditemui kendala yaitu alat pelindung proses intubasi yang ada kurang praktis dan ergonomis. Kebutuhan para dokter adalah alat intubasi yang bisa dibongkar pasang sehingga bisa dengan mudah untuk dibersihkan dan dimensi yang disesuaikan dengan ukuran antropometri pasien.

Keterbatasan dan kendala yang dihadapi tersebut akan coba diatasi dengan melakukan perancangan ulang alat dengan mempertimbangkan aspek ergonomi, ketersediaan bahan dan efesiensi penggunaan bahan. Penelitian dan perancangan alat dilakukan di Teaching Factory Politeknik ATI Padang sementara data antropometri yang digunakan adalah data hasil praktikum Ergonomi mahasiswa Teknik Industri Agro Politeknik ATI Padang tahun 2019.

\section{METODOLOGI}

Tahapan yang dilakukan dalam merancang ulang peralatan intubasi adalah sebagai berikut:

1. Pada tahap awal ini penulis membuat prototype yang menyerupai persis dengan gambar rancangan yang dibuat oleh Department of Anesthesiology Uttaradit Hospital, Thailand yang bertujuan untuk menganalisa bagian yang memungkinkan untuk diminimalisir terutama dalam hal penggunaan bahan baku.

2. Melakukan analisis terhadap prototype awal untuk mendapatkan rancangan yang lebih efesien dan selanjutnya membuat prototype dengan menggunakan hasil analisa tersebut.

3. Melakukan finalisasi akhir terhadap hasil analisa prototype awal untuk mendapatkan prototype akhir yang siap untuk dibuat dalam bentuk finish product
4. Menetapkan ukuran prototype berdasarkan data antropometri yang sudah didapatkan.

Data yang digunakan untuk menentukan dimensi alat adalah data antropometri mahasiswa yang tersedia di Laboratorium Perancangan Sistem Kerja dan Ergonomi. Pada tahap awal terlebih dahulu melakukan uji kecukupan data untuk memastikan jumlah sampel data yang diambil sudah mencukupi. Perhitungan uji kecukupan data dengan menggunakan formula sebagai berikut:

$N^{s}=\left[\frac{\frac{k}{s} \sqrt{N\left(\sum X_{1}^{2}\right)-\left(\sum X_{1}\right)^{2}}}{\sum X_{1}}\right]^{2}$

$\mathrm{N}^{\prime}=$ Banyaknya data yang diperlukan

$\mathrm{S}=$ Tingkat ketelitian

$\mathrm{K}=$ Harga indeks yang besarnya tergantung dari tingkat kepercayaan yang diambil

Pemilihan dimensi akhir dari finish product adalah dengan mempertimbangkan keterpakaian pada sebagian besar populasi sehingga data yang digunakan adalah Persentil 95 (P-95). P-95 artinya adalah produk dapat digunakan pada $95 \%$ populasi, dimana sampel yang digunakan adalah sebagai perwakilan populasi penduduk Provinsi Sumatera Barat.

Metode yang digunakan dalam merancang prototype dan finish product adalah dengan menggunakan pendekatan trial dan error, dimana setiap kemungkinan dikaji oleh penulis dengan tetap berkomunikasi dengan rekat sejawat seorang dokter sebagai end user dari produk tersebut. Trial dan error berhenti ketika end user menyatakan bahwasanya produk akhir sudah layak untuk digunakan.

Tabel 1. Perhitungan Persentil (Sokhibi, 2017)

\begin{tabular}{|l|c|}
\hline \multicolumn{1}{|c|}{ Persentil } & Perhitungan \\
\hline 1-St & $\bar{x}-2,325 \sigma \mathrm{x}$ \\
2.5-th & $\bar{x}-1,96 \sigma \mathrm{x}$ \\
5-th & $\bar{x}-1,645 \sigma \mathrm{x}$ \\
10-th & $\bar{x}-1,28 \sigma \mathrm{x}$ \\
50-th & $\bar{x}$ \\
\hline 90-th & $\bar{x}+1,28 \sigma \mathrm{x}$ \\
95-th & $\bar{x}+1,645 \sigma \mathrm{x}$ \\
97.5-th & $\bar{x}+1,96 \sigma \mathrm{x}$ \\
99-th & $\bar{x}+2,325 \sigma \mathrm{x}$ \\
\hline
\end{tabular}

Alat yang digunakan pada penelitian ini adalah gergaji besi, meteran dan alat tulis sebagai ilustrasi rencana rancangan. Bahan yang digunakan adalah pipa PVC ukuran $1 / 2$ inch dan joint (sambungan) lurus (huruf "I"), sambungan "huruf L" serta sambungan segitiga 
berbentuk huruf "T" dikarenakan sambungan segitiga berbentuk huruf "Y" tidak diproduksi di Indonesia.

\section{HASIL DAN PEMBAHASAN}

Tahapan awal dari penilitian ini adalah melakukan meniru produk berdasarkan rancangan yang dikembangkan oleh Department of Anesthesiology Uttaradit Hospital, Thailand dengan menggunakan alan dan bahan yang tersedia. Hasil dari rancangan tersebut sebagaimana terlihat pada Gambar 2 di bawah ini.

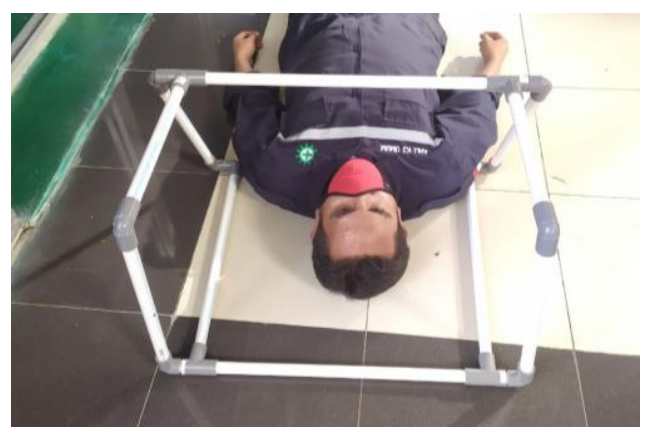

Gambar 2. Proptotype Awal (R I)

Gambar 2 tersebut memperlihatkan bahwasanya prototype awal tidak sama persis dengan gambar rancangan dikarenakan keterbatasan bahan yang ada. Selanjutnya penulis melakukan modifikasi hasil rancangan dengan melakukan re-design dengan mempertimbangkan efesiensi penggunaan bahan.

Perancangan ulang dilakukan dengan menggunakan metode trial dan error dengan mempertimbangkan efesiensi penggunaan bahan. Selain itu juga dipertimbangkan aspek kekuatan dan kekokohan alat karena akan dipakai dalam jangka waktu lama dan frekwensi pemakaian yang cukup sering. Hasil dari perbaikan rancangan tersebut sebagaimana terlihat pada Gambar 3 di bawah ini.

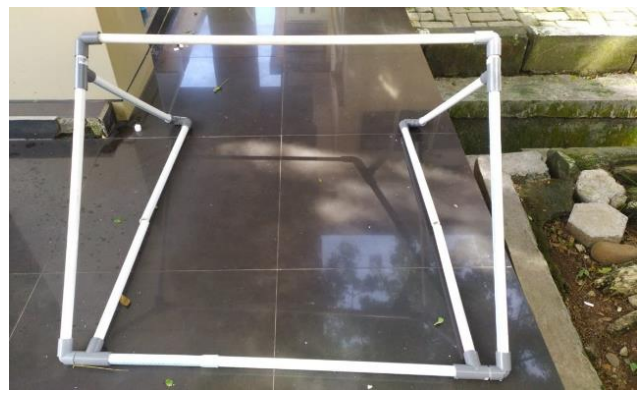

Gambar 3. Perbaikan Hasil Rancangan (R-II)

Gambar 3 tersebut memperlihatkan bahwasanya telah terjadi pengurangan penggunaan bahan baku sebagaimana dapat dilihat pada Tabel 1. Kekurangan pada hasil rancangan ini adalah struktur produk yang kurang kokoh sehingga mudah terlepas jika terjadi benturan yang agak kuat.

Hasil rancangan ini kembali diskusikan dengan end user yang akan menggunakan alat tersebut. Hasil diskusi menyimpulkan bahwasanya produk masih belum efektif dan efesian dan diharapkan produk dapat dengan mudah untuk dibongkar pasang sehingga mudah untuk dibersihkan. Berdasarkan permintaan tersebut kembali dilakukan desain ulang dengan menggunakan prinsip trial dan error. Re-design dan bongkar pasang dilakukan secara berkesinambungan sebanyak 4 (empat) kali didapatkan hasil akhir seperti Gambar 4 di bawah ini.

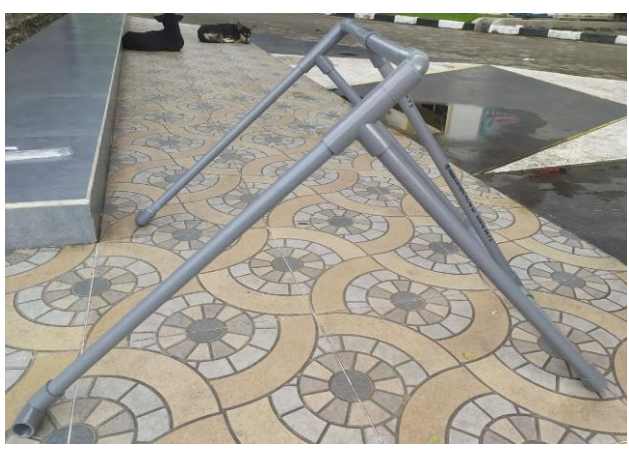

Gambar 4. Hasil Rancangan Akhir (R-III)

Hasil rancangan akhir ini kembali dikonsultasikan lagi dengan end user yang menyatakan bahwasanya alat yang dihasilkan sudah sesuai dengan keinginan dan aspek fungsional yang diminta. Tahapan selanjutnya adalah menetapkan ukuran berdasarkan data antropometri yang sudah tersedia di Laboratorium Perancangan Sistem Kerja dan Ergonomi Jurusan Teknik Industri Agro Politeknik ATI Padang. Adapun data antropometri yang digunakan adalah sebagai berikut:

a. Tinggi alat menggunakan data antropometri Lingkar Kepala (LK)

b. Lebar alat menggunakan data antropometri Lebar Bahu (LB)

Lingkar Kepala (LK) adalah dimensi yang digunakan untuk mengukur keliling kepala sehingga tebal kepala (TK) yang akan dijadikan sebagai dasar menentukan dimensi tinggi alat sama dengan diameter Lingkar Kepala (LK). Konversi dari LK menjadi dengan menggunakan formula perhitungan keliling lingkaran sehingga didapatkan data antropometri seperti di bawah ini. 
Tabel 2. Data Antropometri Lebar Bahu

\begin{tabular}{cccccccc}
\hline No & \multicolumn{7}{c}{ Lebar Bahu (cm) } \\
\hline 1 & 43 & 44 & 40 & 44 & 46 & 37 & 37 \\
2 & 41 & 44 & 36 & 38 & 50 & 40 & 47 \\
3 & 45 & 32 & 37 & 55 & 48 & 43 & 40 \\
4 & 41 & 33 & 34 & 27 & 42 & 30 & 40 \\
5 & 40 & 36 & 35 & 43 & 45 & 36 & 38 \\
6 & 28 & 42 & 46 & 55 & 46 & 43 & 35 \\
7 & 37 & 42 & 40 & 47 & 41 & 40 & 43 \\
8 & 44 & 39 & 28 & 47 & 46 & 40 & 44 \\
9 & 41 & 39 & 29 & 50 & 48 & 43 & 44 \\
10 & 41 & 41 & 32 & 25 & 43 & 45 & 37 \\
11 & 37 & 37 & 41 & 33 & 29 & 46 & \\
12 & 49 & 33 & 43 & 38 & 44 & 43 & \\
13 & 41 & 47 & 35 & 43 & 41 & 41 & \\
14 & 49 & 48 & 43 & 38 & 38 & 43 & \\
15 & 38 & 45 & 41 & 44 & 43 & 45 & \\
\hline
\end{tabular}

(Sumber: Laboratorium PSKE Politeknik ATI Padang)

Data antropemetri berupa Lingkar Kepala (LK) dikonversikan menjadi diameter kepala (DK) dengan cara membagi LK dengan konstanta 22/7 sehingga didapatkanlah datanya sebagai berikut:

Tabel 2. Diameter Kepala (DK)

\begin{tabular}{cccccccc}
\hline No & \multicolumn{7}{c}{ Diameter Kepala $(\mathrm{cm})$} \\
\hline 1 & 16 & 17 & 18 & 18 & 18 & 19 & 18 \\
2 & 17 & 19 & 18 & 19 & 18 & 18 & 17 \\
3 & 18 & 18 & 18 & 19 & 18 & 18 & 18 \\
4 & 19 & 18 & 18 & 17 & 18 & 17 & 19 \\
5 & 18 & 18 & 18 & 18 & 21 & 18 & 18 \\
6 & 19 & 19 & 18 & 18 & 17 & 18 & 18 \\
7 & 18 & 18 & 19 & 17 & 18 & 18 & 18 \\
8 & 18 & 18 & 18 & 18 & 19 & 18 & 18 \\
9 & 18 & 20 & 17 & 20 & 18 & 18 & 17 \\
10 & 18 & 19 & 17 & 19 & 18 & 19 & 17 \\
11 & 18 & 19 & 19 & 18 & 18 & 19 & \\
12 & 18 & 17 & 17 & 18 & 18 & 24 & \\
13 & 18 & 18 & 17 & 19 & 18 & 18 & \\
14 & 18 & 17 & 17 & 17 & 17 & 19 & \\
15 & 18 & 18 & 18 & 18 & 18 & 18 & \\
\hline
\end{tabular}

(Sumber: Laboratorium PSKE Politeknik ATI Padang)

\section{A. Uji Kecukupan Data}

Sebelum data digunakan untuk menentukan dimensi alat, terlebih dahulu dilakukan uji kecukupan data untuk kedua jenis data antropometri tersebut, perhitungannya sebagaimana dijelaskan sebagai berikut:

\section{Lebar Bahu (LB)}

$N^{s}=\left[\frac{\frac{2}{5 \%} \sqrt{100(169240)-(4074)^{2}}}{4074}\right]^{2}$

$N^{p}=31.48$

2. Diameter Kepala (DK)

$N^{s}=\left[\frac{\frac{2}{5 \%} \sqrt{100(32889)-(1811)^{2}}}{1811}\right]^{2}$

$N^{s}=4,48$

Berdasarkan hasil perhitungan tersebut dapat disimpulkan bahwasanya data yang digunakan sudah mencukup karena nilai N' $<100$

\section{B. Perhitungan Dimensi Alat}

Dimensi alat ditetapkan dengan mengacu kepada nilai persentil dari populasi. Persentil 95\% digunakan agar hasil perancangan dapat mencakup sebagian besar populasi dengan menggunakan formula sebagai berikut (Sokhibi, 2017):

$\mathrm{P}-95=\mathrm{R}+1,645 \mathrm{SD}$

Dimana $\mathrm{R} \quad=$ rata-rata

$\mathrm{SD} \quad=$ standar deviasi

Untuk data LB didapatkan nilai

$\mathrm{R} \quad=40.7 \mathrm{~cm}$

$\mathrm{SD} \quad=5.74 \mathrm{~cm}$

Sehingga didapatkan nilai

$\mathrm{P}-95=40.7+1.645(5.47)$

$=50.2 \mathrm{~cm}$

Sementara untuk data DK didapatkan nilai

$\mathrm{R} \quad=18.1 \mathrm{~cm}$

$\mathrm{SD} \quad=0.96 \mathrm{~cm}$

Sehingga didapatkan nilai

P-95 $=18.1+1.645(0.96)$

$=19.7 \mathrm{~cm}$

Data LB dapat digunakan sebagai standar lebar alat namun DK hanya digunakan sebagai acuan. Hasil diskusi dengan end user yang bersangkutan menyarankan untuk tinggi alat adalah 2 kali dari DK sehingga didapatkan tinggi alat sebesar $40 \mathrm{~cm}$. Hasil perhitungan di atas digunakan untuk menentukan dimensi masing-masing komponen pada alat.

Setelah dimensi "tinggi" dan "lebar" didapatkan maka dibuatlah rancangan akhir sebagaimana terlihat pada Gambar 6 telah dilakukan analisa dengan membandingkan pemakaian bahan dari ketiga hasil rancangan tersebut, hasilnya dapat dilihat pada Tabel 3 di bawah ini 
Tabel 3. Perbandingan Penggunaan Material

\begin{tabular}{clccc}
\hline No & Bahan & R-I & R-II & R-III \\
\hline 1 & Pipa (cm) & 420 & 386 & 380 \\
2 & Joint L (pcs) & 8 & 8 & 6 \\
3 & Joint T (pcs) & 6 & 4 & 4 \\
\hline
\end{tabular}

Hasil perbandingan pada Tabel 3 memperlihatkan bahwasanya rancangan akhir lebih hemat dalam penggunaan bahan, baik itu pipa, joint $\mathrm{L}$ ataupun joint T. Semua bahan yang digunakan untuk membuat alat ini berupa pipa PVC berdiameter $1 / 2$ inch. Selain itu hasil perancangan juga telah memenuhi prinsip dan kaidah ergonomi karena menggunakan data antropometri sebagai dasar penentuan dimensi produk serta sesuai dengan keinginan end user. Tahapan selanjutnya adalah penggunaan produk oleh end user dalam skala massal.

\section{KESIMPULAN}

Hasil perancangan dan analisis perbandingan setiap bentuk produk memperlihatkan bahwasanya final product (R-III) merupakan produk yang diusulkan dengan keunggulan lebih hemat, mudah dibongkar pasang (portable) dan sudah memenuhi kaidah ergonomi. Penelitian selanjutnya dapat dilakukan dengan mengkombinasikan perancangan rangka dengan plastik penutup alat secara terintegrasi dalam proses perancangan produk

\section{DAFTAR PUSTAKA}

Handayani, D., Hadi, DR., Isbaniah, F., Burhan, E., Agustin, H. (2020). Penyakit Virus Corona 2019. Jurnal Respirologi Indonesia, 40(2), 119-129.

Ikatan Dokter Indonesia. (2020). Pedoman Standar Perlindungan Dokter Di Era Covid-19. https://www.pdspatklin.or.id/assets/files/pdspatk1 in 2020_09 $09 \quad 18 \quad 05 \quad 48 . p d f$

Laboratorium Perancangan Sistem Kerja dan Ergonomi. (2020). Data Antropometri. Padang: Politeknik ATI Padang.

PERDATIN (Pengurus Perhimpunan Dokter Anestesi dan Terapi Intensif). (2020). Buku Pedoman Penanganan Pasien Kritis Covid-19. https://covid19.idionline.org/wpcontent/uploads/2020/04/14.-BukuPERDATIN.pdf

Sokhibi, Akhmad. (2017). Perancangan Kursi Ergonomis Untuk Memperbaiki Posisi Kerja Pada Proses Packaging Jenang Kudus. Jurnal Rekayasa Sistem Industri, 3(1), 61-72 